\title{
Foraging characteristics of an assemblage of four Sumatran hornbill species
}

\author{
YOK-YOK HADIPRAKARSA and MARGARET F. KINNAIRD
}

\section{Summary}

This study examines the diets of four hornbill species (Bushy-crested Hornbill Anorrhinus galeritus, Wreathed Hornbill Aceros undulatus, Rhinoceros Hornbill Buceros rhinoceros and Helmeted Hornbill Buceros vigil) common within our $9 \mathrm{~km}^{2}$ study area in the Bukit Barisan Selatan National Park, Sumatra, Indonesia. Line transects and opportunistic sampling were used over one year to collect feeding data, including the tree species and strata in which birds fed, diet items, fruit characteristics and tree crop size. Hornbills fed on 64 species. Figs, non-fig fruits and animals comprised $23.4 \%(n=15$ species) $51.6 \%(n=33$ species) and $25 \%$ ( $n=16$ species) of the diet, respectively. Although there was overlap among the diets of the four species, only B. rhinoceros and B. vigil had a statistically significant overlap, primarily due to high fig consumption by both species. B. vigil fed almost exclusively on figs ( $98.6 \%$ of the diet) and a small proportion of animals (1.4\%) while $23.1 \%$ of the B. rhinoceros diet comprised non-fig fruits and animals $(23.1 \%)$, with $76.9 \%$ figs. A. galeritus and A. undulatus had distinct diets with drupaceous, oily fruits comprising $66.7 \%$ and $64.4 \%$ of the diets, respectively. We found no significant relationship between the numbers of hornbills visiting fruiting trees and the characteristics of the fruit (weight, length and width). However, maximum crop sizes of diet species significantly influenced the number of feeding hornbills. Hornbill species also differed in the strata in which they fed. A. galeritus and B. rhinoceros were seen in the middle of the canopy $56 \%$ and $50.8 \%$ of the time, respectively while $A$. undulatus and B. vigil were observed more frequently in the upper canopy $(50 \%$ and $74.3 \%$ of the time, respectively). The lower part of the canopy was used infrequently by all species. This study suggests that the four hornbill species in our study partition food resources by food type and/or feeding location.

\section{Introduction}

All 54 species of hornbills are omnivorous but most rely heavily on fruit (Kemp 1995). Hornbill diets vary over seasons and years due to changes in food abundance and diversity. Diet shifts and changes in selection criteria may also be associated with behavioural changes such as breeding.

Diet selection and the spatial and temporal distribution of feeding may also be influenced by the presence of similar species. Rosenzweig (1995) showed that as the number of similar species increases in an area, each species specializes more narrowly. If coexisting species experience resource limitation, natural selection should result in spatial (Schoener 1974, Sunarto et al. 1999) or temporal partitioning of the ecological niche (Ricklefs 1973). Alternatively, coexisting species may select different resources, such as food items or nesting sites, in order to reduce competition (Schoener 1974, Cody 1985, Rosenzweig 1995). 
Leighton (1982) found that exploitation of fruit resources varied among five species of coexisting Bornean hornbills as a function of morphology, interspecific behaviour and intergroup behaviour. The distribution, availability and characteristics of fruit resources strongly influenced feeding characteristics. For example, large-bodied hornbills tended to consume diet items of lower nutritional quality occurring in large patches while smaller-bodied hornbills were more efficient at exploiting patches containing low numbers of high-quality items.

This study used an approach similar to Leighton's (1982) to examine how an assemblage of four sympatric Sumatran hornbills exploits food resources and how food characteristics vary among species. Dietary composition of Bushycrested Hornbill Anorrhinus galeritus, Wreathed Hornbill Aceros undulatus, Rhinoceros Hornbill Buceros rhinoceros and Helmeted Hornbill Buceros vigil were investigated. All commonly occur within a $9 \mathrm{~km}^{2}$ study area in the Bukit Barisan Selatan National Park, Sumatra. We investigated the influence of fruit availability and fruit morphology on hornbill foraging and the degree of dietary overlap among hornbill species. We then asked whether those hornbill species exhibiting significant dietary overlap partitioned their resources temporally or spatially.

\section{Methods}

\section{Study area}

We conducted our study from September 1998 to December 1999 in the $3,568 \mathrm{~km}^{2}$ Bukit Barisan Selatan National Park (BBSNP), located in south-western Sumatra, Indonesia $\left(4^{\circ} 31^{\prime}-5^{\circ} 57^{\prime} \mathrm{S}\right.$ and $\left.103^{\circ} 34^{\prime}-104^{\circ} 43^{\prime} \mathrm{E}\right)$. The park is the third largest in Sumatra and contains some of the largest tracts of lowland rain forest remaining on the island (O'Brien and Kinnaird 1996). The Way Canguk Research Station is located at $50 \mathrm{~m}$ elevation in the southern section of the park. The study area surrounding the station is $9 \mathrm{~km}^{2}$, consists of primary forest, burned forest and naturally disturbed forest and is divided by the Canguk river. The study area is contiguous with large tracts of primary forest, and areas disturbed by illegal logging and agricultural lands. Annual precipitation ranges from $1,600 \mathrm{~mm}$ in dry years to $4,000 \mathrm{~mm}$ in wetter years, with a short dry season generally occurring between June and September.

\section{Hornbill species}

All nine hornbill species known to occur on Sumatra (Kemp 1995, Rasmussen 2000 in litt.) have been observed in the study site but only Bushy-crested Hornbill Anorrhinus galeritus, Wreathed Hornbill Aceros undulatus, Rhinoceros Hornbill Buceros rhinoceros and Helmeted Hornbill Buceros vigil, are common enough to study. Population densities of these four species vary widely within the Way Canguk study area and fluctuate over time (Anggraini et al. 2000). A. undulatus occurs at the highest average density $\left(7.5\right.$ birds $\left./ \mathrm{km}^{2}\right)$ while $B$. vigil occurs at the lowest average density (1.9 birds $\left./ \mathrm{km}^{2}\right)$. A. galeritus and B. rhinoceros occur at intermediate average densities of 3.05 and 2.6 birds $/ \mathrm{km}^{2}$, respectively.

Of the species studied, A. galeritus is the smallest in size (1,134-1,247 g), strictly territorial and lives in groups of $2-20$, with one dominant breeding pair (Kemp 
1995, Leighton 1986). Of the large-bodied hornbills in our study, A. undulatus $(1,360-3,650 \mathrm{~g})$ is believed to be non-territorial and ranges the most widely (Kemp 1995). Hornbills of the genus Aceros tend to live in pairs but will occasionally flock in large numbers. Aceros hornbills also are known to have some of the largest home ranges of all hornbill species (Poonswad and Tsuji 1994, Suryadi et al. 1998) and their numbers have been shown to fluctuate over time in response to changes in ripe fruit availability (Suryadi et al. 1994, Kinnaird et al. 1996). $B$. rhinoceros and B. vigil are the largest of the hornbills studied $(2,180-2,580 \mathrm{~g}$ and 2,495-3,06o g, respectively), live in pairs and are reported to be territorial (Leighton 1982, Kemp 1995), although Anggraini et al. (2000) reported that B. vigil may not be territorial in southern Sumatra.

\section{Data collection}

We conducted our study from September 1998 to December 1999. Fixed transects and ad libitum sampling (Altmann 1974) were used to collect data. Approximately every 2 weeks we walked 12 transects on the southern side of Canguk river, and six on the north, each $2.2 \mathrm{~km}$ in length. Transects were separated by $200 \mathrm{~m}$. Four different transects were surveyed each day, two in the morning (o6h30-11hoo) and two in afternoon (14hoo-17hoo). Opportunistic observations of feeding hornbills were noted, to augment feeding data collected during standardized walks (Leighton 1982).

Instantaneous scans (Altmann 1974) were used for all observations. Data were recorded on the initial observation of a bird, including: (1) hornbill species observed, (2) number of individuals, (3) position in the tree canopy (lower, middle or upper), (4) if feeding, diet item and fruit type, and (5) estimated crop size of fruiting trees (following methods of Leighton 1993 and Kinnaird et al. 1996). Food items were collected and identified at the field station's herbarium or by the Herbarium Bogoriense. Fruits were weighed wet, measured (longest length and width), and classified by morphology, fruit type (drupaceous, arilate, berry, multi-seeded capsule, and fig) and the characteristics of the endosperm (oily, watery, fleshy).

\section{Data analysis}

Opportunistic data and transect data were combined, as a chi-square analysis found no significant difference between the distribution of feeding records between transect observations and opportunistic data for any species $(P>0.1)$. Chi-square analysis was used (Sokal and Rohlf 1981) to test for differences between species in the distributions of feeding strata, food items (fig fruits, nonfig fruits, animal) and fruit type or morphology. Cole's (1949) Index of Interspecific Association was calculated to examine dietary overlap among species. Cole's index measures zero if two species are distributed independently of each other, approaches +1 if species are completely associated, and -1 if they are not associated. The index is tested for significance with chi-square contingency tables. We also used step-wise multiple regression (Sokal and Rohlf 1981) to examine the relationship between hornbill number and fruit characteristics (crop 
size and fruit size). For this analysis, we used the maximum number of hornbills observed visiting a particular fruiting tree during the study and the maximum crop size observed during the study for each tree species (Leighton 1982). We took the natural log of crop size in order to linearize the data. Fruit length, width, and weights of fleshy parts were averaged for a species and entered into the model as separate variables.

\section{Results}

The hornbill diet, for all species combined, was $23.4 \%$ fig fruits ( $n=15$ species), $51.6 \%$ non-fig fruits ( $n=33$ species) and $25 \%$ small animals ( $n \geq 16$ species). There were significant differences among the species in the percentage of fig, non-fig fruit and animals in the diet $\left(\chi^{2}=134.47, \mathrm{df}=6, P<0.001\right)$. B. vigil and $B$. rhinoceros fed more than expected on fig fruit; this difference contributed the greatest amount to the overall chi-square statistic.

Fruit types (49 species of 5 fruit types) consumed by the different hornbill species were not evenly distributed $\left(\chi^{2}=54.142, \mathrm{df}=12, P<0.001\right.$; Table 1$)$. Overlap was observed among the diets of the four hornbill species, but only B. rhinoceros and $B$. vigil showed significant overlap in the diet species consumed $\left(C_{7}=0.21 \pm 0.09, \chi^{2}=5.48, \mathrm{df}=1, P=0.05, n=48\right)$. This overlap is due to the high degree of fig consumption by both these species.

Hornbills were found in every canopy stratum of the feeding trees, although the four species were not distributed evenly among them $\left(c^{2}=22.4, \mathrm{df}=6\right.$, $P<0.001$; Figure 1). B. vigil was observed more frequently than expected in the upper canopy and less than expected in middle canopy, and contributed the most to the chi-square statistic.

Step-size multiple regression analysis showed a significant positive relationship between the maximum number of all hornbills observed feeding in a tree and the maximum crop size for the tree species $\left(F_{1,46}=26.117 ; P=0.001 ; r^{2}=0.4\right.$; Figure 2); all other factors (mean fruit weight, length and width) were insignificant and were removed from the model. There was a positive relationship between hornbill numbers and maximum crop size for the larger hornbills A. undulatus $\left(F_{1,46}=8.91, r^{2}=0.16, P<0.005\right)$, B. rhinoceros $\left(F_{1,46}=30.3, r^{2}=0.39\right.$, $P<0.001)$ and $B$. vigil $\left(F_{1,46}=21.96, r^{2}=0.32, P<0.001\right)$. There was no significant relationship between hornbill numbers and crop size for the smaller-bodied A. galeritus $(P=0.1)$.

\section{Discussion}

Our results demonstrate that an aggregation of four Sumatran hornbills coexist, in part, by partitioning their diet and by foraging at different levels in the canopy. Two species, A. galeritus and $A$. undulatus, feed on a variety of foods but rely more on lipid-rich drupaceous fruits whereas the larger species, $B$. vigil and $B$. rhinoceros, rely heavily on strangling figs. These findings are similar to those of Leighton $(1982,1986)$ for the same species in Borneo.

The important role that figs play in hornbill abundance and distribution is well documented (Leighton 1982, Poonswad et al. 1986, Kinnaird et al. 1996, Suryadi 
Table 1. Family, species and characteristics of fruit consumed by four hornbill species during the study (Ag, Anorrhinus galeritus; Au, Aceros undulatus; Br, Buceros rhinoceros; Bv, Buceros vigil).

\begin{tabular}{|c|c|c|c|c|c|}
\hline \multirow[t]{2}{*}{ Fruit species } & \multirow[t]{2}{*}{ Fruit characteristic } & \multicolumn{4}{|c|}{ Hornbill species } \\
\hline & & $\mathrm{Ag}$ & $\mathrm{Au}$ & $\mathrm{Br}$ & $\mathrm{Bv}$ \\
\hline \multicolumn{6}{|l|}{ Family Anacardiaceae } \\
\hline Dracontomelon dao & Aril - fleshy & & $X$ & & \\
\hline \multicolumn{6}{|l|}{ Family Apocinaceae } \\
\hline Leuconotis eugeniiflora & Drupe - oily & & & $X$ & \\
\hline \multicolumn{6}{|l|}{ Family Annonaceae } \\
\hline Cananga odorata & Drupe - oily & $X$ & $X$ & & \\
\hline Polyalthia lateriflora & Drupe - oily & & $X$ & & \\
\hline \multicolumn{6}{|l|}{ Family Burseraceae } \\
\hline Canarium denticulatum & Drupe - oily & & $x$ & & \\
\hline Sp1 & Drupe - oily & & $X$ & & \\
\hline Sp2 & Drupe - oily & & $X$ & & \\
\hline $\mathrm{Sp}_{3}$ & Drupe - oily & & & $X$ & \\
\hline Sp4 & Drupe - oily & $X$ & $x$ & & \\
\hline Sp5 & Drupe - oily & $X$ & & & \\
\hline Sp6 & Drupe - oily & & $X$ & & \\
\hline Sp7 & Drupe - oily & & $X$ & & \\
\hline \multicolumn{6}{|l|}{ Family Combretaceae } \\
\hline Terminalia balerica & Drupe - oily & & & $X$ & \\
\hline \multicolumn{6}{|l|}{ Family Cluciaceae } \\
\hline Garcinia dioica & Aril - fleshy & & $X$ & & \\
\hline \multicolumn{6}{|l|}{ Family Cucurbitaceae } \\
\hline Coccinia sp1 & Multi - seed & $X$ & & & \\
\hline Coccinia sp2 & Multi — seed & $x$ & & & \\
\hline \multicolumn{6}{|l|}{ Family Connaraceae } \\
\hline Connarus monocarpus & Aril - fleshy & $X$ & & & \\
\hline \multicolumn{6}{|l|}{ Family Lauraceae } \\
\hline Beilschimiedia lucida & Drupe - oily & $X$ & & & \\
\hline Criptocarya ferrea & Drupe - oily & $x$ & $X$ & $X$ & \\
\hline Litsea garciae & Drupe - oily & & & $X$ & \\
\hline Litsea resinosa & Drupe - oily & & $X$ & & \\
\hline Litsea sp. & Drupe - oily & & $x$ & & \\
\hline \multicolumn{6}{|l|}{ Family Meliaceae } \\
\hline Diospyros truncata & Aril — fleshy & & $X$ & & \\
\hline Dysoxylum arborescens & Aril - fleshy & $X$ & $X$ & & \\
\hline Dysoxylum excelsum & Aril - fleshy & $X$ & $X$ & $X$ & \\
\hline Sp8 & Aril - fleshy & & $x$ & & \\
\hline \multicolumn{6}{|l|}{ Family Moraceae } \\
\hline Antiaris toxicaria & Drupe - oily & $X$ & $x$ & $X$ & \\
\hline Ficus albifila & Fig & $X$ & $X$ & $X$ & $X$ \\
\hline Ficus altissima & Fig & & $x$ & $X$ & $X$ \\
\hline Ficus crassiramera & Fig & & $x$ & $X$ & $X$ \\
\hline Ficus drupaceae & Fig & $X$ & $x$ & $X$ & $X$ \\
\hline Ficus globosa & Fig & $X$ & & $X$ & \\
\hline Ficus microcarpa & Fig & & & & $X$ \\
\hline Ficus stupenda & Fig & $X$ & $X$ & $X$ & $X$ \\
\hline Ficus sundaica & Fig & & & & $X$ \\
\hline Ficus benyamina & Fig & & & & $X$ \\
\hline Ficus spi & Fig & $X$ & $X$ & $X$ & $X$ \\
\hline Ficus sp2 & Fig & & $X$ & $X$ & $X$ \\
\hline Ficus sp3 & Fig & & & $X$ & $X$ \\
\hline Ficus sp4 & Fig & & & $X$ & $X$ \\
\hline Ficus sp5 & Fig & & & $X$ & \\
\hline Ficus sp6 & & & & $X$ & \\
\hline
\end{tabular}


Table 1. Continued.

\begin{tabular}{|c|c|c|c|c|c|}
\hline \multirow[t]{2}{*}{ Fruit species } & \multirow[t]{2}{*}{ Fruit characteristic } & \multicolumn{4}{|c|}{ Hornbill species } \\
\hline & & $\mathrm{Ag}$ & $\mathrm{Au}$ & $\mathrm{Br}$ & $\mathrm{Bv}$ \\
\hline \multicolumn{6}{|l|}{ Family Myristicaceae } \\
\hline Horsfieldia bracteosa & Aril — fleshy & & & $X$ & \\
\hline Knema maxima & Aril - fleshy & & $x$ & & \\
\hline Knета spı & Aril - fleshy & $x$ & & & \\
\hline Knema sp2 & Aril - fleshy & & $X$ & $X$ & \\
\hline \multicolumn{6}{|l|}{ Family Rubiaceae } \\
\hline Zucacarinia macrhophylla & Berry — sugar & $x$ & $x$ & & \\
\hline \multicolumn{6}{|l|}{ Familiy Sterculiaceae } \\
\hline Sterculia sp & Aril — fleshy & & $X$ & & \\
\hline
\end{tabular}

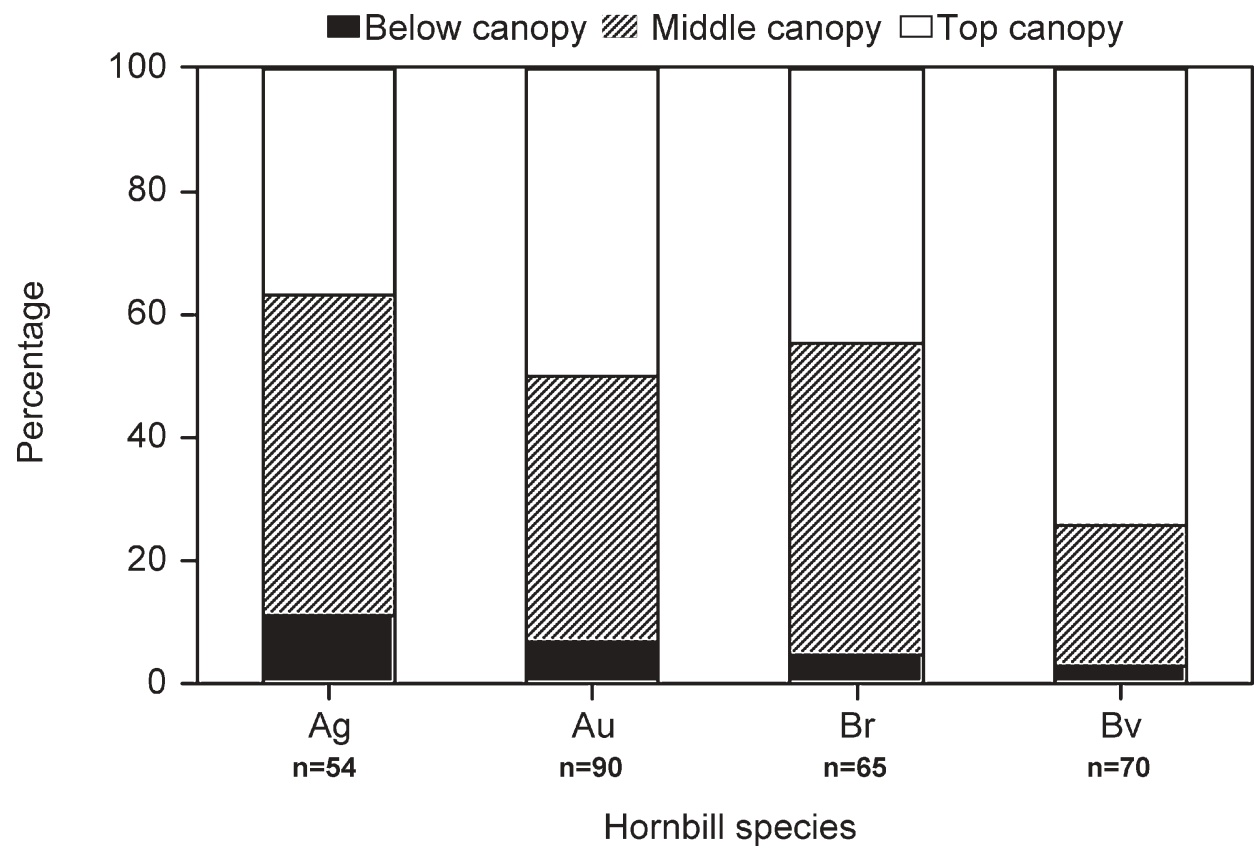

Figure 1. The percentage of observations of four hornbill species in the lower, middle and upper strata of the canopy. Au, Aceros undulatus; Ag, Anorrhinus galeritus; Br, Buceros rhinoceros; Bv, Buceros vigil.

et al. 1994). Leighton and Leighton (1983) and Leighton (1986) argue that hornbills and other frugivores prefer lipid-rich fruits and that they choose figs only when these foods are scarce. A growing body of evidence, however, suggests that figs are preferred foods for many hornbills rather than substitutes ( $\mathrm{O}^{\prime}$ Brien et al. 1998, Kinnaird et al. 1999, Sitompul et al. 2004). Our study shows that B. vigil in southern Sumatra rely almost entirely on figs despite low fig densities relative to other sites.

Figs occur at densities of 0.51 reproductive figs/ha at the Way Canguk study site (Anggaraini et al. 2000) compared with densities of up to 6.6 figs/ha in 


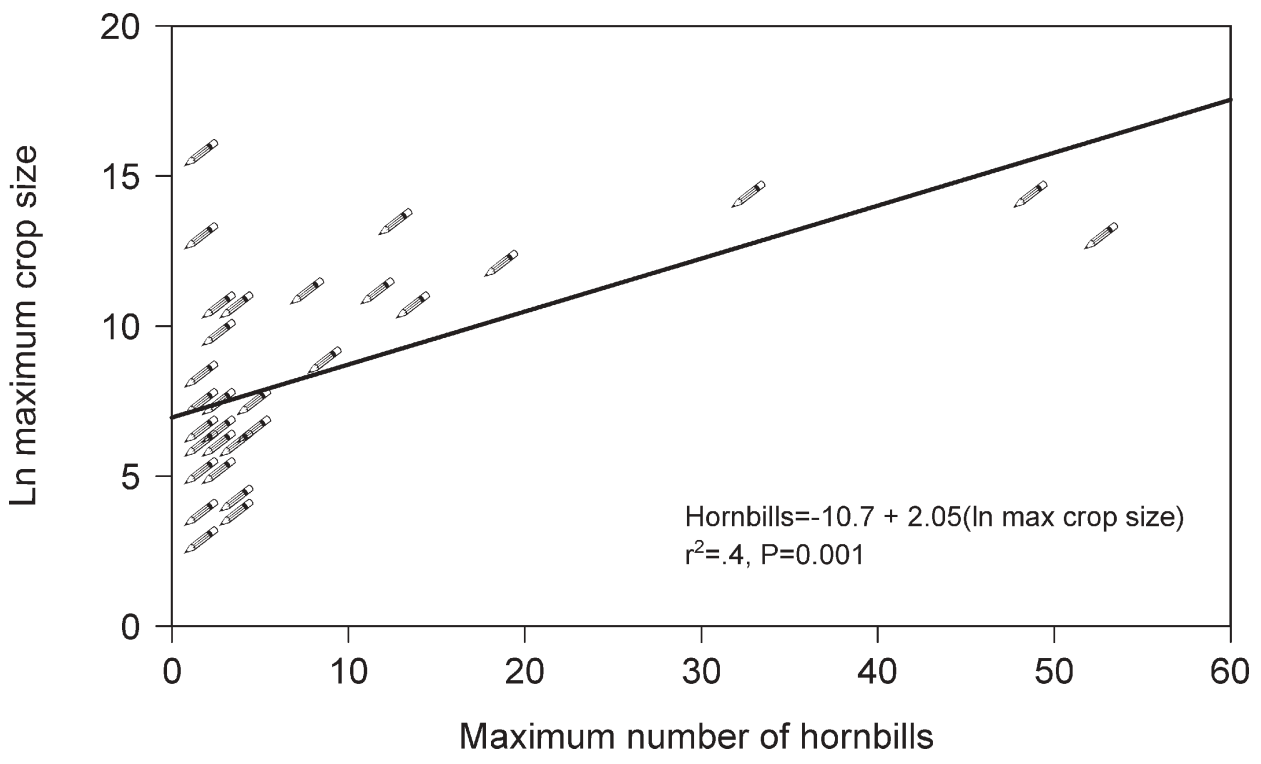

Figure 2. Relationship between the maximum number of hornbill sightings and the natural $\log$ of the maximum crop size for tree species over 15 months of study.

Borneo (Leighton 1982) and 8.3 figs/ha in Sulawesi (Kinnaird et al. 1996). Fig specialization by such large-bodied birds will require that they find big crops, as postulated by Leighton (1982), and move over ranges large enough to provide big crops reliably. Our data for $B$. vigil and $B$. rhinoceros numbers show that larger fig crops attract larger numbers of hornbills and are consistent with this idea. Reliance on figs and the associated long-distance movements necessary to maintain a consistent diet of figs may inhibit territoriality. Anggraini et al. (2000) speculate that B. vigil and B. rhinoceros in southern Sumatra may practice facultative territoriality (Kinnaird 1992), exhibiting territoriality only when resources are limiting and defendable; the smaller, territorial species $A$. galeritus has the most generalized diet and the highest percentage of animal prey. Poonswad (1993) reports similar diet composition for the small-bodied and territorial Austen's Brown Hornbill Anorrhinus austeni, and Oriental Pied Hornbill Anthracoceros albirostris. O'Brien (1997) also shows a generalized diet for the Sulawesi Tarictic Hornbill Penelopides exarhatus exarhatus. These are species that are group-living, are constrained in their movement patterns by territorial boundaries, and display a higher degree of flexibility in exploitation of food resources. A. galeritus often sub-groups while foraging (Leighton 1982, Y. H. pers. obs.), visits small crops of lipid-rich fruits, forages on lianas as well as trees, relies heavily on protein-rich invertebrate prey, and when available visits fruiting figs. Large fruit crops had no relationship to numbers of visiting $A$. galeritus at our site, consistent with the idea that smaller-bodied birds can harvest entire meals and satisfy energetic requirements from smaller crops. Foraging in sub-groups within a territory also enhances the likelihood of a given individual harvesting an entire meal. Alternatively, A. galeritus may be forced to forage on smaller crops due to competitive exclusion by larger hornbills. 
Our study showed that only B. vigil and B. rhinoceros, the largest hornbills, overlap significantly in diet, primarily due to their high intake of figs. We would expect competition for resources to be greatest between these species. Although we did not observe interspecific aggression, we did find spatial partitioning in feeding trees. Three-quarters of our observations of foraging $B$. vigil were in the upper canopy while approximately half our observations of foraging B. rhinoceros were in the mid-canopy. Leighton (1982) reported that displacement among hornbill species was hierarchical, following body size, although he did not observe displacements between $B$. vigil and B. rhinoceros. B. vigil is slightly larger than $B$. rhinoceros and is also reported to be a potential predator on B. rhinoceros chicks (Hetharia 1941 in Kemp 1995), therefore, we may be observing competitive displacement or simply avoidance of $B$. vigil by $B$. rhinoceros. Similarly, we would expect, based on foraging strata, that $A$. undulatus and B. rhinoceros would experience competition while foraging but these species have no significant overlap in diet composition. Although we cannot conclude that there has been competitive exclusion between species pairs, our results are consistent with the hypothesis that this hornbill assemblage is partitioning food resources through diet selection and foraging strata.

\section{Conclusion}

Four hornbill species that commonly occur in the Way Canguk study area of southern Sumatra, Indonesia, showed variability in their dietary composition and may be partitioning resources by selecting different diet species and food types. Two species showing significant dietary overlap foraged at different strata in the canopy, thereby partitioning the resources spatially and possibly reducing competition. Although we found a high diversity of fruits in the study area, figs still played an important role in the diets of the hornbill species studied, especially the larger-bodied species of the genus Buceros. Large fruit crops, which may provide an entire meal, were important in attracting the largerbodied hornbills whereas smaller crops with high lipid content tended to attract the smaller-bodied hornbill. We believe this reflects the differences in foraging efficiencies relative to body size and supports similar findings for Bornean hornbills.

\section{Acknowledgements}

Our study was funded by the Wildlife Conservation Society and conducted in collaboration with the Indonesian Directorate General Nature Protection and Conservation (PKA). We thank Bpk. Sampurno, head of Bukit Barisan National Park for granting permission to conduct research in the park. We are extremely grateful to Puget Sound Chapter of the American Association of Zoo Keepers, at Woodland Park Zoo, Seattle for providing funds for the Y. H. to attend and present this paper at The Third International Hornbill Workshop in Thailand, and to P. Poonswad for financial support to M. K. to attend the workshop. We especially thank our technicians Risdianto, Waryono, Suyadi, Teguh and Marwoto for their assistance in data collection, and M. Iqbal and Sunarto for 
logistical support as the manager of the Way Canguk Research Station. We thank A. Nurcahyo, Ridwan, M. Prasetyaningrum, N. Winarni and A. Dwiyahreni for their friendship while in the field and the time spent discussing our research, and T. O'Brien for analytical advice. M. Marshall, P. Round and G. Gale provided helpful comments on earlier drafts of the manuscript.

\section{References}

Altmann, J. (1974) Observational study of behaviour: sampling methods. Behaviour 49: $227-267$.

Anggraini, K., Kinnaird, M. F. and O'Brien, T. G. (2000) The effects of fruit availability and habitat disturbance on an assemblage of Sumatran hornbills. Bird Conserv. Intn. 10: $189-202$.

Cody, M. L. (1985) Habitat selection in birds. New York: Academic Press.

Cole, L. C. (1949) The measurement of interspecific association. Ecology 30: 411-424.

Kemp, A. C. (1995) The hornbills. London: Oxford University Press.

Kinnaird, M. F. (1992) Variable resource defense by Tana River Crested Mangabey. Behav. Ecol. Sociobiol. 31: 115-122.

Kinnaird, M. F., O’Brien, T. G. and Suryadi, S. (1996) Population fluctuation in Sulawesi Red-Knobbed Hornbill: tracking figs in space and time. Auk 113: 431-440.

Kinnaird, M. F., O'Brien, T. G. and Suryadi, S. (1999) The importance of figs to Sulawesi's imperiled wildlife. Trop. Biodiv. 6: 5-18.

Leighton, M. (1982) Fruit resources and patterns of feeding, spacing and grouping among sympatric Bornean hornbills (Bucerotidae). Unpublished Ph.D. dissertation, University of California, Davis.

Leighton, M. (1986) Hornbill social dispersion: variations on a monogamous theme. Pp. 103-108 in D. Rubenstein and R. W. Wrangham, eds. Ecological aspects of social evolution. Princeton: Princeton University Press.

Leighton, M. (1993) Modeling dietary selectivity by Bornean orangutans: evidence for integration of multiple criteria in fruit selection. Int. J. Primatol. 14: 257-313.

Leighton, M. and Leighton, D. R. (1983) Vertebrate response to fruiting seasonality within a Bornean rainforest. Pp. 181-196 in S. L. Sutton, T. C. Whitmore and A. C. Chadwick, eds. Tropical rainforest: ecology and management. Oxford: Blackwell Scientific.

O'Brien, T. G. (1997) Behavioural ecology of the North Sulawesi Tarictic Hornbill Penelopides exarhatus exarhatus during the breeding season. Ibis 139: 97-101.

O'Brien, T. G. and Kinnaird, M. F. (1996) Birds and mammals of the Bukit Barisan Selatan Park, Sumatra, Indonesia. Oryx 30: 207-217.

O’Brien, T. G., Kinnaird, M. F., Dierenfield, E. S., Conklin-Brittain, N. L., Wrangham, R. W. and Silver, S. C. (1998) What's so special about figs? Nature 392: 668.

Poonswad, P. (1993) Aspects of the biology and ecology of some Asian hornbills. Pp. 7798 in P. Poonswad and A. Kemp, eds. Manual to the Conservation of Asian Hornbills Project, Bangkok, Thailand.

Poonswad, P. and Tsuji, A. (1994) Ranges of males of the Great Hornbill Buceros bicornis, Brown Hornbill Ptelolaemus tickelli and Wreathed hornbill Aceros undulatus in Khao Yai National Park, Thailand. Ibis 136: 79-86.

Poonswad, P., Tsuji, A. and Ngarmpongsai, C. (1986) A comparative ecological study of four sympatric hornbills (Family Bucerotidae) in Thailand. Pp. 2781-2791 in H. Ouellet, ed. Acta XIX Congressus International Ornithologici, vol. II. Ottawa: University of Ottawa.

Ricklefs, R. E. (1973) Ecology. Second edition. New York: Chiron Press.

Rosenzweig, M. L. (1995) Species diversity in space and time. Cambridge: Cambridge University Press.

Schoener, T. W. (1974) Resource partitioning in ecological communities. Science 185: 27-39. 
Sitompul, A. F., Kinnaird, M. F. and O'Brien, T. G. (2004) Size matters: the effects of forest fragmentation and resource availability the endemic Sumba Island Hornbill. Bird Conserv. Intn. 14 (Special Issue), in press.

Sokal, R. R. and Rohlf, F. J. (1981) Biometry. Second edition. New York: W. H. Freeman.

Sunarto, O’Brien T. G, Kinnaird, M. F., Supriatna, J. and Basukriadi, A. (1999) Resource partitioning among kingfishers in Tangkoko-Duasudara Nature Reserve, North Sulawesi. Trop. Biodiv. 1/2: 75-85.

Suryadi, S., Kinnaird, M. F., O’Brien, T. G., Supriatna, J. and Somadikarta, S. (1994) Food preferences of the Sulawesi Red Knobbed Hornbill during the non-breeding season. Trop. Biodiv. 2(3): 377-384.

Suryadi, S., Kinnaird, M. F. and O'Brien, T. G. (1998) Home ranges and daily movements of the Sulawesi Red-Knobbed Hornbill during the non-breeding season. Pp. 159-170 in P. Poonswad, ed. the Asian hornbills: ecology and conservation. Bangkok: Thai Studies in Biodiversity No. 2.

Weins, J. A. (1989) The ecology of bird communities, vol. 1: Foundation and patterns. Cambridge: Cambridge University Press.

YOK-YOK HADIPRAKARSA ${ }^{1}$ and MARGARET F. KINNAIRD ${ }^{1,2}$

${ }^{1}$ Wildlife Conservation Society - Indonesia Program, Jln. Pangrango No. 8, P.O. Box 311, Bogor 16003, Indonesia (e-mail: y.hadiprakarsa@wcsip.org)

${ }^{2}$ Wildlife Conservation Society - Asia Program, 2300 Southern Blvd., Bronx, NY 10460, U.S.A. 